ISSN 1678-3921

Journal homepage: www.embrapa.br/pab

For manuscript submission and journal contents, access: www.scielo.br/pab
Fabiana Schmidt ${ }^{(1 \otimes)}$ and

Ronaldir Knoblauch ${ }^{(2)}$

(1) Empresa de Pesquisa Agropecuária e Extensão Rural de Santa Catarina, Estação Experimental de Campos Novos, BR 282, $\mathrm{Km} 342$, s/no, Boa Vista, CEP 89620-000 Campos Novos, SC, Brazil.

E-mail: fabianaschmidt@epagri.sc.gov.br

(2) Empresa de Pesquisa Agropecuária e Extensão Rural de Santa Catarina, Estação Experimental de Itajaí, Rodovia Antônio Heil, o 6.800, Itaipava, CEP 88318-112 Itajaí, SC, Brazil.

E-mail: ronaldirkn@gmail.com

$\bowtie$ Corresponding author

Received

April 9, 2018

Accepted

November 6, 2019

How to cite

SCHMIDT, F.; KNOBLAUCH, R. Extended use of poultry manure as a nutrient source for floodirrigated rice crop. Pesquisa Agropecuária Brasileira, v.55, e00708, 2020. DOI: https://doi. org/10.1590/S1678-3921.pab2020.v55.00708.

\section{Extended use of poultry manure as a nutrient source for flood-irrigated rice crop}

\begin{abstract}
The objective of this work was to evaluate changes in the soil chemical properties, nitrogen use efficiency, and grain yield of flood-irrigated rice fields after the addition of poultry manure during five years. Trials were carried out in a randomized complete block design, with three replicates. The treatments were: chemical fertilizers, $\mathrm{N}-\mathrm{P}_{2} \mathrm{O}_{5}-\mathrm{K}_{2} \mathrm{O}$; control, no fertilizers; and poultry manure doses, 2.5, 5.0, and $10.0 \mathrm{Mg} \mathrm{ha}^{-1}$. Poultry manure increased soil $\mathrm{pH}$, base saturation, and phosphorus, potassium, calcium, and zinc contents more than the chemical fertilizers. Adding poultry manure to the soil increased $\mathrm{N}$ ammonification $\left(35 \mathrm{mg} \mathrm{kg}{ }^{-1} \mathrm{NH}_{4}^{+}-\mathrm{N}\right.$ ) from the first to the fourth week after rice was sown. The exclusive use of poultry manure was not sufficient to provide adequate nutrition to rice plants after the decrease in $\mathrm{NH}_{4}{ }^{+}-\mathrm{N}$ content in the soil. The cumulative $\mathrm{N}$ uptake by plants and rice yield were lower with poultry manure application than with the chemical fertilizers. Adding poultry manure to flood-irrigated rice fields for five years alters soil chemical properties, improves fertility, does not favor nitrogen use efficiency by rice plants, and promotes a lower grain yield than the chemical fertilizers.
\end{abstract}

Index terms: Oryza sativa, nutrient availability, organic fertilization.

\section{Uso prolongado de cama de aviário como fonte de nutrientes para cultura de arroz irrigado por inundação}

Resumo - O objetivo deste trabalho foi avaliar as propriedades químicas do solo, a eficiência do uso de nitrogênio e a produtividade de campos de arroz irrigado por inundação após adição de cama de aviário durante cinco anos. Os ensaios foram conduzidos em delineamento de blocos ao acaso, com três repetições. Os tratamentos foram: adubação química, $\mathrm{N}-\mathrm{P}_{2} \mathrm{O}_{5}-\mathrm{K}_{2} \mathrm{O}$; controle, sem fertilizantes; e doses de cama de aviário, 2,5, 5,0 e 10,0 $\mathrm{Mg} \mathrm{ha}^{-1}$. A cama de aviário aumentou o $\mathrm{pH}$, a saturação por bases e os teores de fósforo, potássio, cálcio e zinco do solo mais que os fertilizantes químicos. A aplicação de cama de aviário aumentou a amonificação do $\mathrm{N}\left(35 \mathrm{mg} \mathrm{kg}^{-1}\right.$ de $\left.\mathrm{N}-\mathrm{NH}_{4}{ }^{+}\right)$da primeira à quarta semana após a semeadura do arroz. $\mathrm{O}$ uso exclusivo de cama de aviário não foi suficiente para fornecer nutrição adequada ao arroz após a diminuição do conteúdo de $\mathrm{N}-\mathrm{NH}_{4}{ }^{+}$no solo. A absorção acumulada de $\mathrm{N}$ e a produtividade de arroz com a aplicação de cama de aviário foram menores do que as com os fertilizantes químicos. A adição de cama de aviário nas lavouras de arroz por cinco anos altera as propriedades químicas do solo, melhora a fertilidade, não favorece a eficiência do uso de nitrogênio pelas plantas e promove menor produção de arroz que os fertilizantes químicos.

Termos para indexação: Oryza sativa, disponibilidade de nutrientes, adubos orgânicos. 


\section{Introduction}

Rice (Oryza sativa L.) production occupies around 2 million hectares in Brazil, of which irrigated lowland rice covers $65 \%$ or approximately 1,459.9 million hectares. This flood-irrigated rice cropping system has an average yield of 7,500 $\mathrm{kg}$ per hectare. The adequate use of fertilizers in these rice regions is fundamental to achieve great productivity, and the inorganic fertilizers account for an average of $12 \%$ of the variable cost of the rice bag (Oliveira Neto, 2015). The base fertilization is predominantly $\mathrm{P}, \mathrm{K}$, and urea (45-00-00) as a $\mathrm{N}$ source, divided into two or three topdressing applications (Reunião..., 2016).

In contrast, organic fertilizers such as animal manures and green manures are little used as a source of nutrients in rice crops. Therefore, the use of poultry manure in rice fields as an organic fertilizer is a strategy that enables, at the same time, a correct form of disposal of these residues and a fertilization method capable of improving the physical, chemical and biological characteristics of the soil (McGrath et al., 2010).

Several authors have shown that organic amendments play a crucial role in both short-term nutrient supply and long-term build-up of soil quality in flood-irrigated rice crops (Javier et al., 2002; Knoblauch et al. 2012; Nishikawa et al., 2014). In addition, when properly managed, they decrease potential polluters and increase yield, which makes them important sources of income and added value, since they are resources available on the farms and may be used in organic production (Liang et al., 2017; Mushtaq et al., 2019).

Fertilization using poultry manure should consider the crop's requirements and the manure's speed of decomposition and nutrient release, as well as its nutrient concentration, because most of them are part of organic compounds and need to be mineralized to become available to the plants. Therefore, one of the main obstacles to the use of organic manures in rice production is crop nutrition, mainly $\mathrm{N}$ supply to the production system (Javier et al., 2002; Masunga et al., 2016).

In flood-irrigated rice, organic fertilizers must be incorporated into dry soil approximately 30 days before soil flooding and rice sowing, to enable the mineralization process and to prevent the formation of organic acids during the anaerobic decomposition of organic material (Reunião..., 2016). Applying poultry manure to rice plants at their developmental stages has negative practical implications and causes environmental pollution (Nishikawa et al., 2014).

In flooded soils, information about nutrient release from poultry manure to the soil are scarce. Therefore, understanding the dynamics of nutrient release following poultry manure application to waterlogged soils is necessary to establish the adequate quantities to achieve high yield and decrease environmental impacts to soil and water. In addition to establishing organic residual doses, it is important to compare the rice yields obtained using organic fertilizer with those obtained using mineral fertilization.

Therefore, it is necessary to evaluate if the use of poultry manure provides $\mathrm{N}$ in an available form and in adequate amounts to increase rice crop productivity, and also if, after a long time of continuous use of poultry manure in rice fields, there is an increase in soil fertility when compared with other rice fields treated only with chemical fertilizers.

The objective of this work was to evaluate changes in the soil chemical properties, nitrogen use efficiency, and grain yield of flood-irrigated rice fields after the addition of poultry manure during five years.

\section{Materials and Methods}

The trial started in 2012 in a paddy field at the experimental station of Empresa de Pesquisa Agropecuária e Extensão Rural de Santa Catarina, located in the municipality of Itajaí, in the state of Santa Catarina, Brazil $\left(26^{\circ} 57^{\prime} 10^{\prime \prime} \mathrm{S}, 48^{\circ} 45^{\prime} 40^{\prime \prime} \mathrm{W}\right.$, at a 7-m altitude). The soil is a lowland soil, classified as Cambissolo háplico (Santos et al., 2013), i.e., an Inceptisol. Samples were collected at the $0-20-\mathrm{cm}$ soil depth before the beginning of the experiments. The soil's chemical characteristics were: $\mathrm{pH} 4.9$ in $\mathrm{H}_{2} \mathrm{O}$, $13.9 \mathrm{~g} \mathrm{~kg}^{-1}$ organic carbon, $6.1 \mathrm{mg} \mathrm{dm}{ }^{-3} \mathrm{P}$ (Mehlich-1), $71.9 \mathrm{mg} \mathrm{dm}^{-3}$ exchangeable $\mathrm{K}$ (Mehlich-1), 8.07 $\mathrm{cmol}_{\mathrm{c}} \mathrm{dm}^{-3}$ cation exchange capacity, $1.6 \mathrm{cmol}_{\mathrm{c}} \mathrm{dm}^{-3}$ $\mathrm{Ca}, 0.9 \mathrm{cmol}_{\mathrm{c}} \mathrm{dm}^{-3} \mathrm{Mg}$, and base saturation of $30 \%$.

The experiment was conducted in a randomized complete block design consisting of five treatments with three replicates over five years. The experimental area of each plot was $7 \times 6 \mathrm{~m}\left(42 \mathrm{~m}^{2}\right)$, separated by clay levees between plots. The treatments were: inorganic fertilizers, i.e., $\mathrm{N}-\mathrm{P}_{2} \mathrm{O}_{5}-\mathrm{K}_{2} \mathrm{O}$ applied as urea, superphosphate, and potassium chloride; three doses of poultry manure, totally basal application of 2.5, 5.0 and 
10.0 $\mathrm{Mg} \mathrm{ha}{ }^{-1}$; and control, without inorganic fertilizers and poultry manure. Inorganic fertilizers were applied every year at the following rates: $120 \mathrm{~kg} \mathrm{ha}^{-1}$ total $\mathrm{N}$ (urea), with a split topdressing application ( $1 / 3$ at early tillering $+1 / 3$ at tillering $+1 / 3$ at heading); $40 \mathrm{~kg} \mathrm{ha}^{-1}$ $\mathrm{P}_{2} \mathrm{O}_{5}$, and $70 \mathrm{~kg} \mathrm{ha}^{-1} \mathrm{~K}_{2} \mathrm{O}$, with totally basal application.

The chemical properties of the poultry manure were determined according to Tedesco et al. (1995) (Table 1). Dry mass was quantified by the difference between wet and oven-dried samples weight. The contents of $\mathrm{N}, \mathrm{P}, \mathrm{K}, \mathrm{Ca}$, and $\mathrm{Mg}$ were measured after the wet digestion of the soil samples by using sulfuric acid and hydrogen peroxide. Poultry manure was applied to and incorporated into dry soil four weeks before sowing, to ensure microbial activity occurred. The poultry manure used in crops had an average percentage of $\mathrm{N}$, $\mathrm{P}$ and $\mathrm{K}$ of 2.1, $4.0\left(\mathrm{P}_{2} \mathrm{O}_{5}\right)$ and $2.1 \%\left(\mathrm{~K}_{2} \mathrm{O}\right)$, respectively. Therefore, the three doses of poultry manure contained approximately 50,100 , and $200 \mathrm{~kg} \mathrm{ha}^{-1} \mathrm{~N}$, respectively. In 2014, limestone was applied and mixed to the topsoil by plowing in all plots of the experimental area.

The rice cultivar used was SCS118 Marques, characterized by late maturity, at around 142 days of the biological cycle. In each season, $120 \mathrm{~kg} \mathrm{ha}^{-1}$ pre-germinated seeds were sown in the flooded soil. All the plots were submerged in 5 to $10 \mathrm{~cm}$ water depth from the sowing to the heading stage. Pest management practices were conducted in accordance with recommendations by Sociedade Sul-Brasileira de Arroz Irrigado (Reunião..., 2016). During yearly harvest, the rice grains were removed from the field, and the stubble and underground portions were kept fallow until the next cropping season.

Table 1. Chemical properties of the solid poultry manure applied in soil over five years (2012-2016) in flood-irrigated rice (Oryza sativa) crop.

\begin{tabular}{lccccccc}
\hline $\begin{array}{l}\text { Growing } \\
\text { season }\end{array}$ & $\mathrm{pH}$ & $\begin{array}{c}\text { Dry } \\
\text { matter }\end{array}$ & $\begin{array}{c}\text { Total } \\
\mathrm{N}\end{array}$ & $\mathrm{P}_{2} \mathrm{O}_{5}$ & $\mathrm{~K}_{2} \mathrm{O}$ & $\mathrm{Ca}$ & $\mathrm{Mg}$ \\
\hline $2011 / 2012$ & 8.2 & 81.0 & 2.87 & 5.25 & 2.49 & 1.9 & 0.57 \\
$2012 / 2013$ & 8.1 & 86.4 & 2.03 & 2.99 & 1.32 & 3.31 & 1.02 \\
$2013 / 2014$ & 8.4 & 77.6 & 2.38 & 3.44 & 2.40 & 1.97 & 1.34 \\
$2014 / 2015$ & 8.6 & 79.7 & 1.94 & 4.66 & 1.08 & 3.92 & 0.55 \\
$2015 / 2016$ & 8.9 & 83.4 & 1.42 & 3.84 & 3.06 & 3.92 & 1.58 \\
\hline Mean & 8.4 & 81.6 & 2.13 & 4.04 & 2.07 & 3.00 & 1.01 \\
\hline
\end{tabular}

In all treatments, the soil in the $0-20-\mathrm{cm}$ plowed layer was annually sampled after harvest from 2012 to 2016. Samples were air dried and sieved through a 2.0-mm mesh for chemical analyses: exchangeable K, $\mathrm{Ca}, \mathrm{Mg}$, and available $\mathrm{P}$; subsequently, the sum of the bases, cation exchange capacity at $\mathrm{pH} 7.0$, and base saturation were calculated as recommended by Tedesco et al. (1995). The $\mathrm{Al}^{3+}$ and $\mathrm{H}+\mathrm{Al}$ were determined by titration techniques (Alvarez et al., 2001), whereas $\mathrm{Zn}$ was extracted by Mehlich-1 and determined using atomic absorption spectrophotometry. $\mathrm{pH}$ in $\mathrm{H}_{2} \mathrm{O}$ was obtained using a soil-water ratio of 1:2.5. Organic carbon content (OC) was determined using the WalkeyBlack method (Silva, 2009).

$\mathrm{NH}_{4}{ }^{+}-\mathrm{N}$ content in the $0-10-\mathrm{cm}$ soil layer was determined at scheduled intervals after field flooding. The soil was sampled using a soil sampler with a small homemade screw auger. After that, soil samples were transported immediately to the laboratory, thoroughly mixed, and analyzed for moisture content in soil (the method is based on removing soil moisture by oven drying a soil sample at $105^{\circ} \mathrm{C}$ until its weight remains constant). The concentration of $\mathrm{NH}_{4}{ }^{+}-\mathrm{N}$ was determined using $1 \mathrm{~mol} \mathrm{~L}^{-1} \mathrm{KCl}$ solution $(10 \mathrm{~g}$ field-moist soil in $50 \mathrm{~mL}$ solution). For mineral $\mathrm{N}$, soil slurries were shaken for 1 hour in the MA244/IHM low-speed reciprocal shaker (Marconi, Piracicaba, SP, Brazil). Two hours after shaking, a $20-\mathrm{mL}$ solution was analyzed to determine $\mathrm{NH}_{4}{ }^{+}-\mathrm{N}^{2}$ and $\mathrm{NO}_{3}{ }^{-}-\mathrm{N}$ using the micro Kjeldahl method.

At the maturation stage, aboveground residual straw and grains were collected from $1 \mathrm{~m}^{2}$ of each plot. The samples were dried in a forced-air ventilation oven at $65^{\circ} \mathrm{C}$ for 72 hours, and ground. Analyses were performed to determine $\mathrm{N}$ content using the micro Kjeldahl method (Tedesco et al., 1995). $\mathrm{N}$ accumulation in the aboveground residual straw and grains was calculated using dry mass and $\mathrm{N}$ concentration data.

Grain yield was determined by harvesting a sample area of $6.0 \mathrm{~m}^{2}$ per plot. The grain yield weight was adjusted to a $13 \%$ moisture content. Yield components (panicles per square meter, grains per panicle, panicle sterility, 1,000-grain weight, and harvest index) were determined by harvesting a sample area of $0.25 \mathrm{~m}^{2}$ in the center of each plot. After counting their number, the panicles were manually threshed and the filled grains were separated from the unfilled grains (half- 
filled and empty grains) using a weed sorting machine powered by a $1 / 2$-hp engine.

Statistical analysis was performed using the $\mathrm{R}$ statistical software (R Core Team, 2015). Analysis of variance was used to detect significance between regression coefficients. The mean rice yield values for the poultry manure, inorganic fertilizer and control (no fertilization) treatments were compared using the Tukey's test to detect significant differences among treatments at a $5 \%$ probability.

\section{Results and Discussion}

The poultry manure applied yearly before rice sowing resulted in higher $\mathrm{pH}$ in the soil than chemical fertilization (Table 2). Before the poultry manure application, soil $\mathrm{pH}$ values in all plots varied within a relatively narrow range, from 4.90 to 5.03. After four years, comparing 2012 and $2016(\Delta)$, the difference in soil $\mathrm{pH}$ showed higher decrease under the control treatment and NPK fertilization than under the poultry manure treatment. Only with $10.0 \mathrm{Mg}$ ha ${ }^{-1}$ poultry manure the $\Delta$ value was positive $(+0.27)$. From the second year on, soil $\mathrm{pH}$ increased along with the increase in the manure dose applied. The regression coefficient was significant with linear adjustment of equations from the second until the fifth year (Table 2).

The soil $\mathrm{pH}$ increase due to the poultry manure treatment may be explained by many factors, such as the dissociation of alkaline products which are present in the composition of the animals' diet, the metabolic activities of organic compounds, and protein degradation, which liberates ammonia into the environment (Mushtaq et al., 2019), as well the use of calcium oxide during poultry house disinfection (Wolf et al., 2014). Poultry manure's

Table 2. Changes in $\mathrm{pH}$ in $\mathrm{H}_{2} \mathrm{O}$, base saturation (BS), and organic carbon (OC) in soil fertilized with inorganic fertilizers and doses of poultry manure during five years, from 2012 to 2016, under 'SCS118 Marques' flood-irrigated rice (Oryza sativa) crop.

\begin{tabular}{|c|c|c|c|c|c|c|}
\hline Treatment & 2012 & 2013 & 2014 & 2015 & 2016 & $\Delta^{(1)}$ \\
\hline & \multicolumn{6}{|c|}{$\mathrm{pH} \mathrm{H} \mathrm{H}_{2} \mathrm{O}$} \\
\hline $\mathrm{N}-\mathrm{P}_{2} \mathrm{O}_{5}-\mathrm{K}_{2} \mathrm{O}$ & 4.93 & 4.97 & 4.97 & 4.97 & 4.57 & -0.37 \\
\hline \multicolumn{7}{|l|}{ Poultry manure } \\
\hline $0 \mathrm{Mg} \mathrm{ha}^{-1}$ & 4.90 & 4.87 & 5.00 & 5.00 & 4.63 & -0.27 \\
\hline $2.5 \mathrm{Mg} \mathrm{ha}^{-1}$ & 4.77 & 5.10 & 4.93 & 5.17 & 4.77 & 0.00 \\
\hline $5.0 \mathrm{Mg} \mathrm{ha}^{-1}$ & 5.03 & 5.13 & 5.10 & 5.30 & 4.93 & -0.10 \\
\hline $10.0 \mathrm{Mg} \mathrm{ha}^{-1}$ & 4.97 & 5.33 & 5.23 & 5.40 & 5.23 & +0.27 \\
\hline Equation & $\hat{y}^{\mathrm{ns}}$ & $\hat{y}=4.92+0.04 * x$ & $\hat{y}=4.95+0.03 * x$ & $\hat{y}=5.05+0.05 * x$ & $\hat{y}=4.63+0.06^{* *} x$ & \\
\hline \multirow[t]{2}{*}{$\mathrm{R}^{2}$} & & 0.92 & 0.81 & 0.92 & 0.99 & \\
\hline & \multicolumn{6}{|c|}{ Base saturation (\%) } \\
\hline $\mathrm{N}-\mathrm{P}_{2} \mathrm{O}_{5}-\mathrm{K}_{2} \mathrm{O}$ & 32.6 & 36.8 & 52.5 & 23.3 & 20.9 & -11.7 \\
\hline \multicolumn{7}{|l|}{ Poultry manure } \\
\hline $0 \mathrm{Mg} \mathrm{ha}^{-1}$ & 30.6 & 31.5 & 45.5 & 29.3 & 21.8 & -8.8 \\
\hline $2.5 \mathrm{Mg} \mathrm{ha}^{-1}$ & 30.9 & 41.9 & 47.6 & 32.3 & 26.2 & -4.7 \\
\hline $5.0 \mathrm{Mg} \mathrm{ha}^{-1}$ & 40.3 & 45.9 & 51.7 & 42.8 & 33.3 & -7.0 \\
\hline 10.0 $\mathrm{Mg} \mathrm{ha}^{-1}$ & 27.6 & 61.4 & 61.3 & 50.5 & 51.2 & +23.6 \\
\hline Equation & $\hat{\mathrm{y}}^{\mathrm{ns}}$ & $\hat{y}=32.58+2.88 * * x$ & $\hat{y}=44.39+1.62 * * x$ & $\hat{y}=28.97+2.23 * x$ & $\hat{y}=19.98+3.00 * * x$ & \\
\hline \multirow[t]{2}{*}{$\mathrm{R}^{2}$} & & 0.98 & 0.98 & 0.95 & 0.98 & \\
\hline & \multicolumn{6}{|c|}{ Organic carbon $\left(\mathrm{g} \mathrm{dm}^{-3}\right)$} \\
\hline $\mathrm{N}-\mathrm{P}_{2} \mathrm{O}_{5}-\mathrm{K}_{2} \mathrm{O}$ & 14.1 & 10.8 & 12.8 & 19.5 & 12.4 & -1.7 \\
\hline \multicolumn{7}{|l|}{ Poultry manure } \\
\hline $0 \mathrm{Mg} \mathrm{ha}^{-1}$ & 13.8 & 8.9 & 11.0 & 18.9 & 10.8 & -3.1 \\
\hline $2.5 \mathrm{Mg} \mathrm{ha}^{-1}$ & 14.2 & 10.4 & 12.8 & 17.6 & 11.2 & -3.3 \\
\hline $5.0 \mathrm{Mg} \mathrm{ha}^{-1}$ & 14.6 & 9.7 & 12.2 & 18.6 & 12.6 & -1.4 \\
\hline $10.0 \mathrm{Mg} \mathrm{ha}^{-1}$ & 15.4 & 10.1 & 12.8 & 16.8 & 11.2 & -4.4 \\
\hline Equation & $\hat{y}=13.78+0.16^{* *} x$ & $\hat{y}^{\text {ns }}$ & $\hat{\mathrm{y}}^{\mathrm{ns}}$ & $\hat{\mathrm{y}}^{\mathrm{ns}}$ & $\hat{\mathrm{y}}^{\mathrm{ns}}$ & \\
\hline $\mathrm{R}^{2}$ & 0.99 & & & & & \\
\hline
\end{tabular}

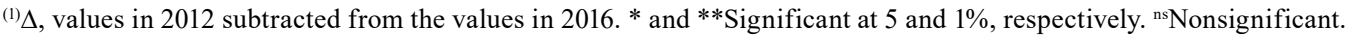


performance on increasing soil $\mathrm{pH}$ depends on the amount of calcium oxide received as treatment, which promotes acidity correction.

Poultry manure's $\mathrm{pH}$ was around 8.0-9.0; therefore, its addition contributed to raising the soil's $\mathrm{pH}$ (Table 1). In the experimental area, where soil $\mathrm{pH}$ was low, the manure addition produced benefits to the soil's chemical conditions. The increase in soil $\mathrm{pH}$ produced by the use of poultry manure in areas with Fe toxicity may promote positive effects on rice productivity, by reducing the environment's toxicity to the plants' roots, because it produces smaller amounts of $\mathrm{H}^{+}$for the electron supply and therefore decreases and retards the $\mathrm{Fe}$ and $\mathrm{Mn}$ transformations.

Base saturation (BS) increased along with poultry manure doses' increase after the second year of application (Table 2). Differences in BS between 2012 and 2016 increased only under the treatment with 10.0 $\mathrm{Mg} \mathrm{ha}^{-1}$ manure. In the fifth year, BS values under the $\mathrm{N}-\mathrm{P}_{2} \mathrm{O}_{5}-\mathrm{K}_{2} \mathrm{O}$ and control treatments were around $20 \%$, but with $10.0 \mathrm{Mg} \mathrm{ha}^{-1}$ poultry manure the BS values increased to $51.2 \%$. BS increase in the soil occurred due to the cumulative amount of $\mathrm{Ca}^{2+}$ and $\mathrm{K}^{+}$provided by poultry manure (Tables 2 and 3 ). The incorporation

Table 3. Changes in $\mathrm{P}, \mathrm{K}, \mathrm{Ca}, \mathrm{Mg}$, and $\mathrm{Zn}$ availabilities in soil fertilized with inorganic fertilizers and poultry manure doses during five years, from 2012 to 2016, under 'SCS118 Marques' flood-irrigated rice (Oryza sativa) crop.

\begin{tabular}{|c|c|c|c|c|c|c|}
\hline Treatment & 2012 & 2013 & 2014 & 2015 & 2016 & $\Delta^{(1)}$ \\
\hline & \multicolumn{6}{|c|}{$\mathrm{P}\left(\mathrm{mg} \mathrm{dm}^{-3}\right)$} \\
\hline $\mathrm{N}-\mathrm{P}_{2} \mathrm{O}_{5}-\mathrm{K}_{2} \mathrm{O}$ & 5.6 & 10.4 & 7.8 & 6.8 & 13.2 & +7.6 \\
\hline \multicolumn{7}{|l|}{ Poultry manure } \\
\hline $0 \mathrm{Mg} \mathrm{ha}^{-1}$ & 6.1 & 9.4 & 8.4 & 5.0 & 7.6 & +1.5 \\
\hline $2.5 \mathrm{Mg} \mathrm{ha}^{-1}$ & 6.7 & 11.6 & 10.2 & 7.9 & 9.0 & +2.3 \\
\hline $5.0 \mathrm{Mg} \mathrm{ha}^{-1}$ & 7.7 & 13.2 & 11.9 & 11.7 & 15.2 & +7.5 \\
\hline $10.0 \mathrm{Mg} \mathrm{ha}^{-1}$ & 7.1 & 15.9 & 16.8 & 15.7 & 26.5 & +19.4 \\
\hline Equation & $\hat{\mathrm{y}}^{\mathrm{ns}}$ & $\hat{y}=9.77+0.63 * * x$ & $\hat{y}=8.19+0.83^{*} * x$ & $\hat{y}=5.37+1.07 * * x$ & $\hat{y}=5.93+1.98 * * x$ & \\
\hline \multirow[t]{2}{*}{$\mathrm{R}^{2}$} & & 0.99 & 0.99 & 0.98 & 0.97 & \\
\hline & \multicolumn{6}{|c|}{$\mathrm{K}\left(\mathrm{mg} \mathrm{dm}^{-3}\right)$} \\
\hline $\mathrm{N}-\mathrm{P}_{2} \mathrm{O}_{5}-\mathrm{K}_{2} \mathrm{O}$ & 70.8 & 97.3 & 83.4 & 57.3 & 47.9 & -22.8 \\
\hline \multicolumn{7}{|l|}{ Poultry manure } \\
\hline $0 \mathrm{Mg} \mathrm{ha}^{-1}$ & 71.9 & 76.0 & 82.2 & 54.7 & 36.9 & -35.0 \\
\hline $2.5 \mathrm{Mg} \mathrm{ha}^{-1}$ & 95.1 & 86.7 & 104.3 & 69.3 & 47.9 & -47.2 \\
\hline $5.0 \mathrm{Mg} \mathrm{ha}^{-1}$ & 91.6 & 98.7 & 105.5 & 88.0 & 71.6 & -20.0 \\
\hline $10.0 \mathrm{Mg} \mathrm{ha}^{-1}$ & 120.6 & 120.0 & 147.2 & 118.0 & 124.7 & +4.1 \\
\hline Equation & $\hat{y}=75.38+4.44 * x$ & $\hat{\mathrm{y}}=76.00+4.42^{* *} \mathrm{x}$ & $\hat{y}=82.70+6.19 * x$ & $\hat{y}=54.53+6.39^{* *} x$ & $\hat{y}=30.67+9.06^{* *} x$ & \\
\hline \multirow[t]{2}{*}{$\mathrm{R}^{2}$} & 0.90 & 0.99 & 0.95 & 0.99 & 0.98 & \\
\hline & \multicolumn{6}{|c|}{$\mathrm{Ca}\left(\mathrm{cmol}_{\mathrm{c}} \mathrm{dm}^{-3}\right)$} \\
\hline $\mathrm{N}-\mathrm{P}_{2} \mathrm{O}_{5}-\mathrm{K}_{2} \mathrm{O}$ & 1.90 & 1.93 & 3.60 & 0.93 & 1.57 & -0.33 \\
\hline \multicolumn{7}{|l|}{ Poultry manure } \\
\hline $0 \mathrm{Mg} \mathrm{ha}^{-1}$ & 1.67 & 1.77 & 3.40 & 1.10 & 1.50 & -0.17 \\
\hline $2.5 \mathrm{Mg} \mathrm{ha}^{-1}$ & 1.73 & 2.50 & 3.93 & 1.63 & 2.37 & +0.63 \\
\hline $5.0 \mathrm{Mg} \mathrm{ha}^{-1}$ & 2.10 & 2.77 & 3.97 & 2.10 & 3.13 & +1.03 \\
\hline $10.0 \mathrm{Mg} \mathrm{ha}^{-1}$ & 2.37 & 3.97 & 4.57 & 3.13 & 4.83 & +2.47 \\
\hline Equation & $\hat{y}=1.64+0.07 * x$ & $\hat{\mathrm{y}}=1.82+0.21 * * \mathrm{x}$ & $\hat{y}=3.49+0.11 * x$ & $\hat{y}=1.11+0.20 * * x$ & $\hat{y}=1.51+0.33^{* *} \mathrm{x}$ & \\
\hline \multirow[t]{2}{*}{$\mathrm{R}^{2}$} & 0.95 & 0.98 & 0.94 & 0.99 & 0.99 & \\
\hline & \multicolumn{6}{|c|}{$\mathrm{Zn}\left(\mathrm{mg} \mathrm{dm}^{-3}\right)$} \\
\hline $\mathrm{N}-\mathrm{P}_{2} \mathrm{O}_{5}-\mathrm{K}_{2} \mathrm{O}$ & 2.17 & 2.77 & 2.57 & 3.50 & 2.33 & +0.17 \\
\hline \multicolumn{7}{|l|}{ Poultry manure } \\
\hline $0 \mathrm{Mg} \mathrm{ha}^{-1}$ & 2.57 & 4.33 & 2.43 & 2.90 & 2.53 & -0.03 \\
\hline $2.5 \mathrm{Mg} \mathrm{ha}^{-1}$ & 2.73 & 4.13 & 2.93 & 2.93 & 3.00 & +0.27 \\
\hline $5.0 \mathrm{Mg} \mathrm{ha}^{-1}$ & 3.23 & 3.93 & 2.93 & 3.10 & 4.30 & +1.07 \\
\hline $10.0 \mathrm{Mg} \mathrm{ha}^{-1}$ & 2.93 & 5.87 & 3.87 & 4.27 & 5.40 & +2.47 \\
\hline Equation & $\hat{\mathrm{y}}^{\mathrm{n}}$ & $\hat{\mathrm{y}}^{\mathrm{ns}}$ & $\hat{y}=2.45+0.14 * x$ & $\hat{y}=2.68+0.14 * x$ & $\hat{y}=2.5+0.30 * * x$ & \\
\hline $\mathrm{R}^{2}$ & & & 0.94 & 0.86 & 0.97 & \\
\hline
\end{tabular}

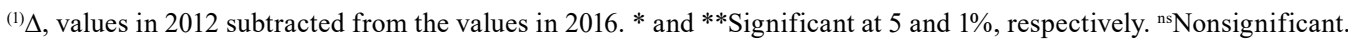


of $10 \mathrm{Mg} \mathrm{ha}^{-1}$ poultry manure per year added $174 \mathrm{~kg} \mathrm{~K}$, $300 \mathrm{~kg} \mathrm{Ca}$, and $100 \mathrm{~kg} \mathrm{Mg}$ per hectare to the soil. The $\mathrm{N}-\mathrm{P}_{2} \mathrm{O}_{5}-\mathrm{K}_{2} \mathrm{O}$ fertilizer supplied only $58 \mathrm{~kg} \mathrm{ha}^{-1} \mathrm{~K}$.

The soil's $\mathrm{K}$ and $\mathrm{Ca}$ contents increased significantly under the manure treatments (Table 3). For $\mathrm{K}$ and $\mathrm{Ca}$ contents, the adjusted regression equations were linear for poultry manure treatments in all years. In 2014, soil $\mathrm{Ca}$ content increased under all treatments, because limestone was applied to the experimental area. In the long term, the use of poultry manure as a nutrient source may supply high amounts of $\mathrm{K}, \mathrm{Ca}$, and $\mathrm{Mg}$ to the soil (Table 3). The levels of $\mathrm{N}, \mathrm{P}, \mathrm{K}, \mathrm{Ca}$, and $\mathrm{Mg}$ in poultry manure vary according to its origin, and especially to its chemical/biochemical composition (Table 1).

Organic carbon (OC) contents in the plowed soil increased with manure doses only in the first year (Table 2). In later years, OC contents in the plots with poultry manure did not differ in comparison to the other treatments. This is due to several factors, such as the greater production of straw and its incorporation to the soil in plots where chemical fertilizers were used, which compensated for the $\mathrm{C}$ contained in organic fertilizers in the plots under poultry manure treatments. Studies developed by Huang et al. (2013) and Yadvinder-Singh et al. (2010) showed that straw crop residue retention is an important source of soil organic matter and an effective strategy for maintaining soil fertility and crop yields in the vast agricultural areas of China. In addition, in paddy soils, organic matter is more liable to accumulate than in upland soils, due to the submerged conditions during the rice crop's growth period, because submerged rice paddies are maintained at lower redox potentials.

Chemical fertilizer and control plots had less soil $\mathrm{Zn}$ content than the treatments with addition of poultry manure (Table 3). The value of $\Delta \mathrm{Zn}$ was higher for 5.0 and $10.0 \mathrm{Mg} \mathrm{ha}^{-1}$ manure doses than for the other treatments. Phosphorous contents in the soil increased significantly under the manure treatments. In subsequent years, the $\mathrm{P}$ content increased in response to manure use, with linear adjustment of the equations. The value of $\Delta \mathrm{P}$ was higher under the $10.0 \mathrm{Mg} \mathrm{ha}^{-1}$ poultry manure dose than under the inorganic fertilization treatment. At the fifth year, the value of $\mathrm{P}$ content in the plowed soil under the $10.0 \mathrm{Mg} \mathrm{ha}^{-1}$ poultry-manure treatment was very high, $26.5 \mathrm{mg} \mathrm{dm}^{-3}$. In the present study, the $\mathrm{P}$ accumulated in the soil was higher under poultry manure than under chemical fertilization.
In flood-irrigated rice, care must be taken to properly manage poultry manure (fresh or composted) usage, because continuous and intensive use of organic manure increase $\mathrm{P}$ accumulation in the soil (Table 3). Organic fertilizers are alternatives to chemical fertilizers for P supply (Regmi et al., 2002), however P release from poultry manure can be slower than from chemical fertilizers. According to Zai et al. (2010), microbial activity is higher in soils fertilized with poultry manure, and this activity helps to release $\mathrm{P}$ from soil and increases plant uptake.

The highest $\mathrm{NH}_{4}{ }^{+} \mathrm{N}$ contents in the plowed soil layer under the poultry manure treatments occurred at approximately 20 to 40 days after sowing (Figure 1). In this period, the treatment with $10 \mathrm{Mg} \mathrm{ha}^{-1}$ poultry manure applied before sowing reached the highest contents of $\mathrm{NH}_{4}{ }^{+}-\mathrm{N}, 35 \mathrm{mg} \mathrm{kg}^{-1}$ in the four growing seasons. From the first to the fourth week, the application of poultry manure to the soils markedly increased $\mathrm{N}$ ammonification (about $30 \mathrm{mg} \mathrm{kg}^{-1}$ $\mathrm{NH}_{4}{ }^{+}-\mathrm{N}$ ), which is attributed to amounts of soluble carbohydrates, low $\mathrm{C} / \mathrm{N}$ ratio and low amount of lignin, resulting in high microbial activity and thus in faster decomposition of the poultry manure applied (Griffiths et al., 1994). Generally, this favors all microbial groups and particularly stimulates the ammonium producers.

After this period, $\mathrm{NH}_{4}{ }^{+} \mathrm{N}$ contents in the soil decreased under the manure treatments, and the values reached 5 to $10 \mathrm{mg} \mathrm{kg}^{-1} \mathrm{NH}_{4}{ }^{+}-\mathrm{N}$. The decrease in $\mathrm{NH}^{+}-\mathrm{N}$ content in the soil 40 days after sowing shows that the exclusive use of poultry manure may not be sufficient to provide adequate nutrition to rice plants during the period of high demand for $\mathrm{N}$, since the rate of $\mathrm{N}$ released from organic manures was relatively low.

Poultry manure contains $\mathrm{N}$ in organic forms, but the rate and extent of its mineralization and $\mathrm{N}$ availability is slow. A long-term evaluation showed that the incorporation of poultry manure to the soil as a $\mathrm{N}$ source before rice sowing is not an efficient practice to nourish the plants in the period of high demand for $\mathrm{N}$, which occurs from the full tillering stage forward (Figure 1). At the panicle differentiation stage (around 80 days after sowing), $\mathrm{NH}^{+}-\mathrm{N}$ content in the soil decreased when poultry manure was applied in totally basal dressing.

However, the split application of urea increased the efficiency of $\mathrm{N}$ use by plants. The highest amounts of $\mathrm{NH}_{4}{ }^{+} \mathrm{N}$ in the soil, about 20 to $55 \mathrm{mg} \mathrm{kg}^{-1}$, occurred 
after the first urea application (24 to 46 days after sowing) in all years. The increase in $\mathrm{NH}_{4}{ }^{+}-\mathrm{N}$ content was only detected after the first urea application, because during the second and third applications the plants had vigorous vegetative development, with high consumption rates of the $\mathrm{NH}_{4}{ }^{+} \mathrm{N}$ available in the soil. Also, the inorganic $\mathrm{N}$ is subject to escaping the paddy soil towards the environment as gaseous $\mathrm{N}_{2}$, by denitrification, and as nitrate, by leaching and mainly by ammonia volatilization or by nitrificationdenitrification (Watanabe et al., 2009).

Inorganic fertilizer (NPK) and poultry manure doses increased rice grain yield in comparison to the control treatment (no fertilization) in all four harvests
(Figure 2). The highest yields were obtained under the chemical fertilizer treatment, in which the mean yield was $9,896 \mathrm{~kg} \mathrm{ha}^{-1}$, which depicts a $38 \%$ increase in comparison to the control treatment. The poultry manure doses incorporated before sowing produced $19 \%$ less grain yield when compared to chemical fertilizers.

Grain yield increased in a quadratic model arrangement when poultry manure doses increased in the range of 0 to $10 \mathrm{Mg} \mathrm{ha}^{-1}$ (Figure 3). Based on regression equations, maximum grain yield was obtained with the application of $6.8 \mathrm{Mg} \mathrm{ha}^{-1}$ poultry manure doses in the first harvest, $8.2 \mathrm{Mg} \mathrm{ha}^{-1}$, in the second, $5.6 \mathrm{Mg} \mathrm{ha}^{-1}$, in the third, and $6.6 \mathrm{Mg} \mathrm{ha}^{-1}$, in the
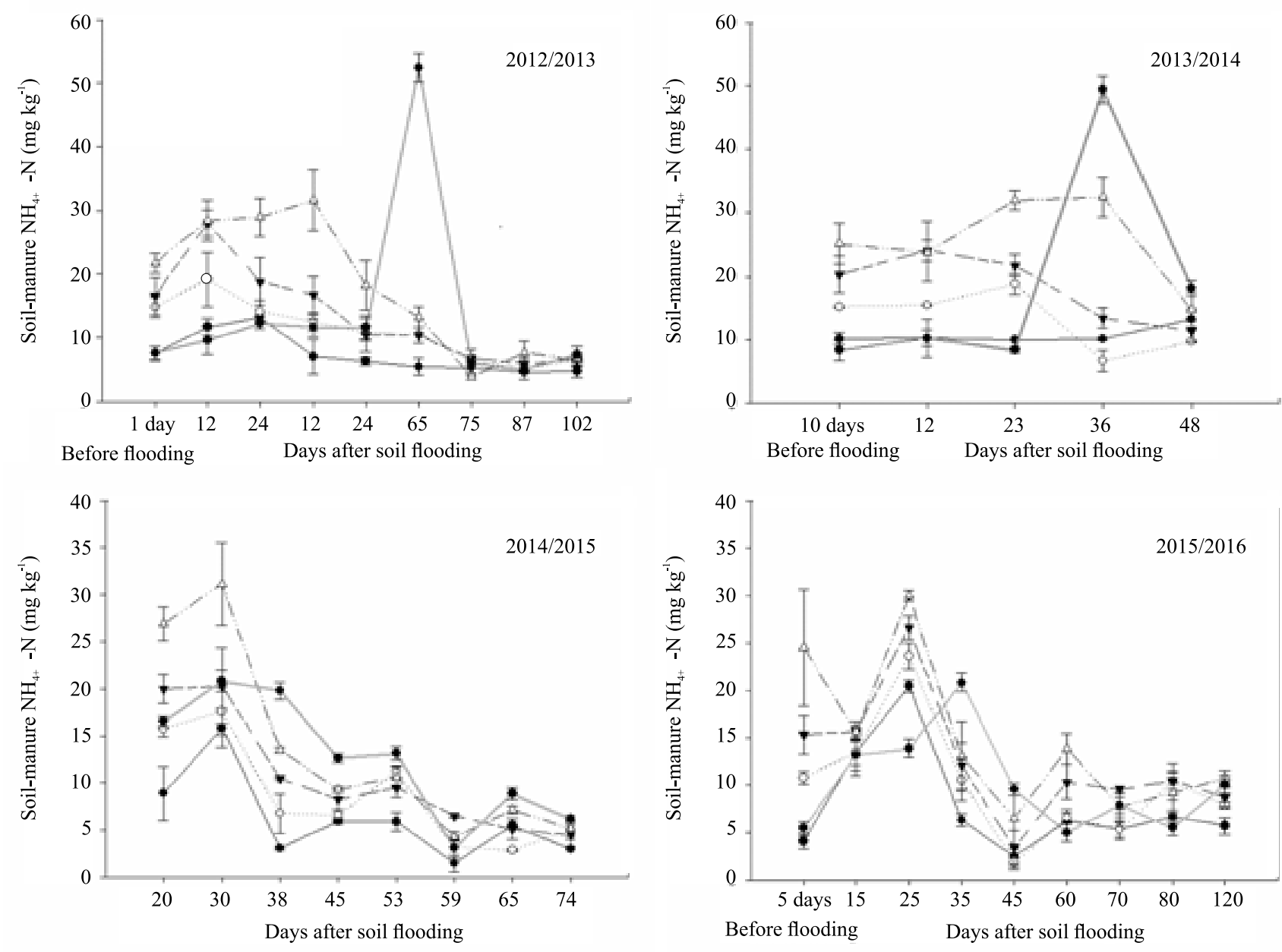

$\longrightarrow \quad 0.0 \mathrm{Mg} \mathrm{ha}^{-1} \mathrm{PM}$

……… $\quad 2.5 \mathrm{Mg} \mathrm{ha}^{-1} \mathrm{PM}$

$5.0 \mathrm{Mg} \mathrm{ha}^{-1} \mathrm{PM}$

$-\cdots-\triangle-\cdots-\quad 10.0 \mathrm{Mg} \mathrm{ha}^{-1} \mathrm{PM}$

$\longrightarrow \quad$ Urea

Figure 1. Soil-manure $\mathrm{NH}_{4}^{+}-\mathrm{N}$ days after the application of poultry manure (PM) and inorganic fertilizer (urea) to the soil. Vertical error bars indicate a mean standard error. 
fourth. The maximum grain yields estimated varied from 8.2 to $8.8 \mathrm{Mg} \mathrm{ha}^{-1}$ in all four harvests.

Rice yield under the application of poultry manure did not reach the productivity of the chemical fertilization treatment. However, the maximum yields obtained in the four years may be considered high $(8,000$ to 8,800 $\left.\mathrm{kg} \mathrm{ha}^{-1}\right)$, because they are higher than the rice mean yields for the state of Santa Catarina $\left(7,500 \mathrm{~kg} \mathrm{ha}^{-1}\right)$. The poultry manure doses that promoted maximum rice yields supplied 130 to $190 \mathrm{~kg} \mathrm{ha}^{-1} \mathrm{~N}, 190$ to 350 $\mathrm{kg} \mathrm{ha}^{-1} \mathrm{P}_{2} \mathrm{O}_{5}$, and 70 to $170 \mathrm{~kg} \mathrm{ha}^{-1} \mathrm{~K}_{2} \mathrm{O}$. Thus, poultry manure, when used in adequate doses, may be an efficient organic fertilizer, and reduce the demand for external $\mathrm{N}$ (urea) in rice fields.

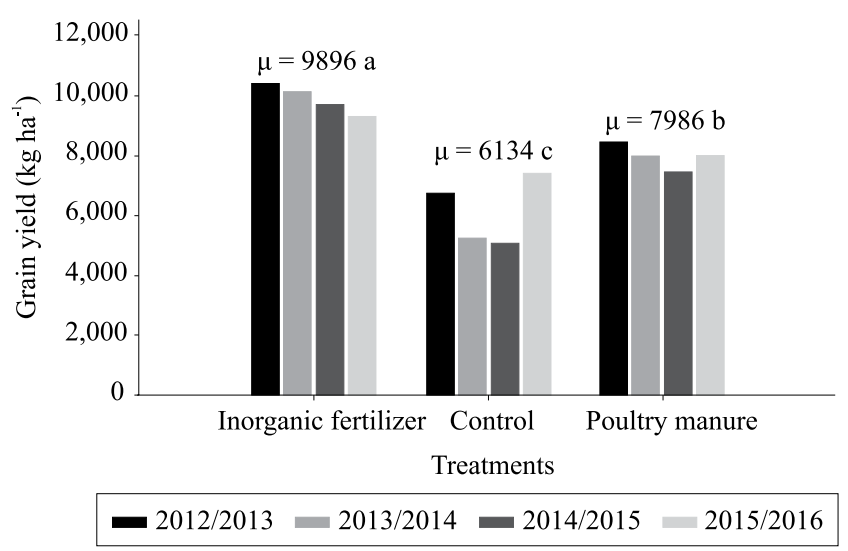

Figure 2. 'SCS118 Marques' flood-irrigated rice (Oryza sativa) yield, as affected by poultry manure, inorganic fertilizer $\left(\mathrm{N}-\mathrm{P}_{2} \mathrm{O}_{5}-\mathrm{K}_{2} \mathrm{O}\right)$, and control (without fertilization) treatments. Values are the means $(\mu)$ of four years, and equal letters ddo not iffer by Tukey's test, at a 5\% probability.
Rice plants supplied with chemical fertilizers produced more panicles per area and grains per panicle than rice plants supplied with poultry manure doses. However, both yield components increased significantly with the increase in manure doses (Table 4). Grain sterility, thousand grain weight and harvest index were not affected by fertilizer type poultry manure or chemical. Nitrogen concentration in straw and grains was not affected by fertilizer type or poultry manure dose (Table 5). The highest $\mathrm{N}$

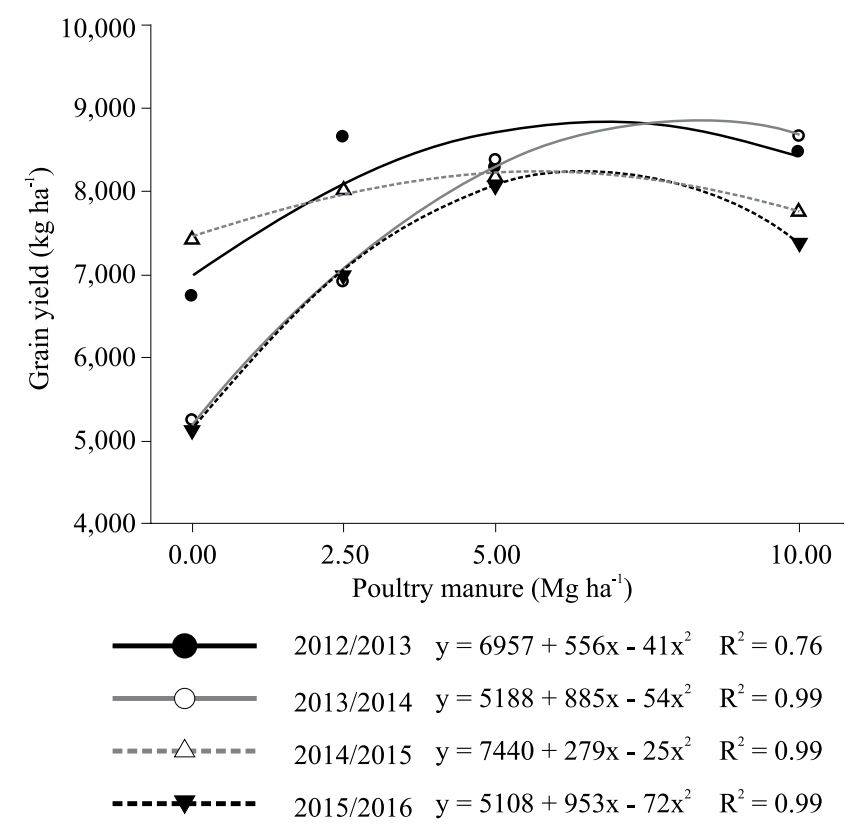

Figure 3. 'SCS118 Marques' flood-irrigated rice (Oryza sativa) yield in response to the application of poultry manure doses. *Significant at $5 \%$.

Table 4. Yield components of 'SCS118 Marques' flood-irrigated rice grown in soil fertilized with doses of poultry manure and with inorganic fertilizer $\left(\mathrm{N}-\mathrm{P}_{2} \mathrm{O}_{5}-\mathrm{K}_{2} \mathrm{O}\right)$ during five years, from 2012 to 2016.

\begin{tabular}{|c|c|c|c|c|c|}
\hline Treatment & $\begin{array}{l}\text { Panicles per } \mathrm{m}^{2} \\
\text { (no.) }\end{array}$ & $\begin{array}{c}\text { Grains per panicle } \\
\text { (no.) }\end{array}$ & $\begin{array}{l}\text { 1,000-grain weight } \\
(\mathrm{g})\end{array}$ & $\begin{array}{c}\text { Grain sterility } \\
(\%)\end{array}$ & $\begin{array}{c}\text { Harvest index } \\
(\%)\end{array}$ \\
\hline $\mathrm{N}-\mathrm{P}_{2} \mathrm{O}_{5}-\mathrm{K}_{2} \mathrm{O}$ & 575 & 64 & 30 & 15 & 49 \\
\hline \multicolumn{6}{|l|}{ Poultry manure } \\
\hline $0 \mathrm{Mg} \mathrm{ha}^{-1}$ & 489 & 45 & $29^{\text {ns }}$ & $11^{\mathrm{ns}}$ & 50 \\
\hline $2.5 \mathrm{Mg} \mathrm{ha}^{-1}$ & 532 & 51 & 30 & 12 & 54 \\
\hline $5.0 \mathrm{Mg} \mathrm{ha}^{-1}$ & 562 & 52 & 30 & 11 & 53 \\
\hline $10.0 \mathrm{Mg} \mathrm{ha}^{-1}$ & 555 & 59 & 30 & 12 & 48 \\
\hline Equation & $\hat{y}=487+22.3 * x-1.6 * x^{2}$ & $\hat{y}=45.6+1.4 * x$ & $\hat{\mathrm{y}}^{\mathrm{ns}}$ & $\hat{y}^{\text {ns }}$ & $\hat{\mathrm{y}}^{\mathrm{ns}}$ \\
\hline $\mathrm{R}^{2}$ & 0.99 & 0.97 & & & \\
\hline
\end{tabular}

* and $* *$ Significant at 5 and $1 \%$, respectively. ${ }^{\text {ns Nonsignificant. }}$ 
Table 5. Nitrogen content in straw and grains, and $\mathrm{N}$ accumulated in straw, grains and total for 'SCS118 Marques' floodirrigated rice (Oryza sativa) grown in soil fertilized with doses of poultry manure and with inorganic fertilizer $\left(\mathrm{N}^{-} \mathrm{P}_{2} \mathrm{O}_{5^{-}}\right.$ $\mathrm{K}_{2} \mathrm{O}$ ) during five years, from 2012 to 2016.

\begin{tabular}{|c|c|c|c|c|c|}
\hline \multirow[t]{2}{*}{ Treatment } & \multicolumn{2}{|c|}{$\mathrm{N}$ content $(\%)$} & \multicolumn{3}{|c|}{$\mathrm{N}$ accumulated $\left(\mathrm{kg} \mathrm{ha}^{-1}\right)$} \\
\hline & Straw & Grains & Straw & Grains & Straw+grains \\
\hline $\mathrm{N}-\mathrm{P}_{2} \mathrm{O}_{5}-\mathrm{K}_{2} \mathrm{O}$ & 0.61 & 0.99 & 64.14 & 96.67 & 160.81 \\
\hline \multicolumn{6}{|l|}{ Poultry manure } \\
\hline $0 \mathrm{Mg} \mathrm{ha}^{-1}$ & 0.50 & 0.88 & 30.51 & 52.64 & 83.15 \\
\hline $2.5 \mathrm{Mg} \mathrm{ha}^{-1}$ & 0.51 & 0.87 & 32.31 & 64.86 & 97.16 \\
\hline $5.0 \mathrm{Mg} \mathrm{ha}^{-1}$ & 0.49 & 0.90 & 35.71 & 74.15 & 109.86 \\
\hline 10.0 $\mathrm{Mg} \mathrm{ha}^{-1}$ & 0.50 & 0.92 & 44.17 & 73.92 & 118.09 \\
\hline Equation & $\hat{\mathrm{y}}^{\mathrm{ns}}$ & $\hat{\mathrm{y}}^{\mathrm{ns}}$ & $\hat{y}=29+1.4 * * x$ & $\hat{y}=52+6.3 * x-0.4 * x^{2}$ & $\hat{y}=87+3.4^{*} x$ \\
\hline $\mathrm{R}^{2}$ & & & 0.98 & 0.99 & 0.91 \\
\hline
\end{tabular}

* and ${ }^{* *}$ Significant at 5 and $1 \%$, respectively. ${ }^{\mathrm{n}}$ Nonsignificant.

accumulation was achieved in rice plants grown using chemical fertilizers $\left(64.14 \mathrm{~kg} \mathrm{ha}^{-1}\right.$ accumulated in the straw and $96.6 \mathrm{~kg}$ exported to the grains), while plants supplied with poultry manure treatments accumulated 32.31 to $44.17 \mathrm{~kg} \mathrm{ha}^{-1}$ in the straw and 64.86 to 73.92 $\mathrm{kg} \mathrm{ha}^{-1}$ in the grains.

The use of chemical fertilizers, especially split nitrogen, improved the synchronicity between $\mathrm{N}$ supply and $\mathrm{N}$ uptake and use by the rice crop, and increased the yield components.

\section{Conclusion}

Adding poultry manure to the soil in flood-irrigated rice (Oryza sativa) fields for five years alters the chemical properties of the soil, improves fertility, but does not favor the efficiency of nitrogen use by rice plants, and favors grain yield less than chemical fertilizers.

\section{Acknowledgments}

To Fundação de Amparo à Pesquisa e Inovação do Estado de Santa Catarina (Fapesc), for financial support.

\section{References}

ALVAREZ V., V.H.; DIAS, L.E.; RIBEIRO JUNIOR, E.S.; SOUZA, R.B.; FONSECA, C.A. da. Métodos de análise de enxofre em solos e plantas. Viçosa: UFV, 2001. 131p.

GRIFFITHS, B.S.; VAN VUUREN, M.M.I.; ROBINSON, D. Microbial grazer populations in a ${ }^{15} \mathrm{~N}$ labelled organic residue and the uptake of residue $\mathrm{N}$ by wheat. European Journal of
Agronomy, v.3, p.321-325, 1994. DOI: https://doi.org/10.1016/ s1161-0301(14)80161-5.

HUANG, S.; ZENG, Y.; WU, J.; SHI, Q.; PAN, X. Effect of crop residue retention on rice yield in China: a metaanalysis. Field Crops Research, v.154, p.188-194, 2013. DOI: https://doi.org/10.1016/j.fcr.2013.08.013.

JAVIER, E.F.; MARQUEZ, J.M.; GROSPE, F.S.; MAMUCOD, H.F.; TABIEN, R.E. Three-year effect of organic fertilizer use on paddy rice. Philippine Journal of Crop Sciences, v.27, p.11-15, 2002.

KNOBLAUCH, R.; ERNANI, P.R.; DESCHAMPS, F.C.; GATIBONI, L.C.; EBERHARDT, D.S.; STUKER, H. Dinâmica do nitrogênio em solos alagados, contaminação da água de irrigação e rendimento de grãos de arroz em decorrência da aplicação de fertilizantes nitrogenados químicos e orgânicos. Revista Agropecuária Catarinense, v.25, p.67-72, 2012.

LIANG, X.; JIN, Y.; HE, M.; LIU, Y.; HUA, G.; WANG, S.; TIAN, G. Composition of phosphorus species and phosphatase activities in a paddy soil treated with manure at varying rates. Agriculture, Ecosystems and Environment, v.237, p.173-180, 2017. DOI: https://doi.org/10.1016/j.agee.2016.12.033.

MASUNGA, R.H.; UZOKWE, V.N.; MLAY, P.D.; ODEH, I.; SINGH, A.; BUCHAN, D.; NEVE, S. de. Nitrogen mineralization dynamics of different valuable organic amendments commonly used in agriculture. Applied Soil Ecology, v.101, 185-193, 2016. DOI: https://doi.org/10.1016/j.apsoil.2016.01.006.

MCGRATH, S.; MAGUIRE, R.O.; TRACY, B.F.; FIKE, J.H. Improving soil nutrition with poultry litter application in lowinput forage systems. Agronomy Journal, v.102, p.48-54, 2010. DOI: https://doi.org/10.2134/agronj2009.0198.

MUSHTAQ, M.; IQBAL, M.K.; KHALID, A.; KHAN, R.A. Humification of poultry waste and rice husk using additives and its application. International Journal of Recycling of Organic Waste in Agriculture, v.8, p.15-22, 2019. DOI: https://doi.org/10.1007/s40093-018-0224-8. 
NISHIKAWA, T.; LI, K.; INAMURA, T. Nitrogen uptake by the rice plant and changes in the soil chemical properties in the paddy rice field during yearly application of anaerobically-digested manure for seven years. Plant Production Science, v.17, p.237244, 2014. DOI: https://doi.org/10.1626/pps.17.237.

OLIVEIRA NETO, A.A. (Org.). A cultura do arroz. Brasília: Conab, 2015. 180p.

R CORE TEAM. R: a language and environment for statistical computing. Vienna: R Foundation for Statistical Computing, 2015.

REGMI, A.P.; LADHA, J.K.; PATHAK, H.; PASUQUIN, E.; BUENO, C.; DAWE, D.; HOBBS, P.R.; JOSHY, D.; MASKEY, S.L.; PANDEY, S.P. Yield and soil fertility trends in a 20 -year rice-rice-wheat experiment in Nepal. Soil Science Society of America Journal, v.66, p.857-867, 2002. DOI: https://doi.org/10.2136/sssaj2002.8570.

REUNIÃO TÉCNICA DA CULTURA DO ARROZ IRRIGADO, 31., 2016, Bento Gonçalves. Arroz Irrigado: recomendações técnicas da pesquisa para o Sul do Brasil. Pelotas: SOSBAI, 2016. Available at: <http://www.sosbai.com.br/>. Accessed on: Nov. 62019.

SANTOS, H.G. dos; JACOMINE, P.K.T.; ANJOS, L.H.C. dos; OLIVEIRA, V.Á. de; LUMBRERAS, J.F.; COELHO, M.R.; ALMEIDA, J.A de; CUNHA, T.J.F.; OLIVEIRA, J.B. de. Sistema brasileiro de classificação de solos. 3 ed. rev. e ampl. Brasília: Embrapa, 2013. 353p.

SILVA, F.C da (Ed). Manual de análises químicas de solos, plantas e fertilizantes. 2.ed. rev. e ampl. Brasília: Embrapa Informação Tecnológica, 2009. 627p.
TEDESCO, M.; GIANELLO, C.; BISSIANI, C.A.; BOHNEM, H.; VOLKWEISS, S.J. Análise de solo, plantas e outros materiais. 2.ed. rev. e ampl. Porto Alegre: UF RGS, 1995.

WATANABE, T.; SON, T.T.; HUNG, N.N.; VAN TRUONG, N.; GIAU, T.Q.; HAYASHI, K.; ITO, O. Measurement of ammonia volatilization from flooded paddy fields in Vietnam. Soil Science and Plant Nutrition, v.55, p.793-799, 2009. DOI: https://doi.org/10.1111/j.1747-0765.2009.00419.x.

WOLF, J.; GOUVEA, A. de; SILVA, E.R.L. da; POTRICH, M.; APPEL, A. Métodos físicos e cal hidratada para manejo do cascudinho dos aviários . Ciencia Rural, v.44, p.161-166, 2014.

YADVINDER-SINGH; GUPTA, R.K.; JAGMOHAN-SINGH; GURPREET-SINGH; GOBINDER-SINGH; LADHA, J.K. Placement effects on rice residue decomposition and nutrient dynamics on two soil types during wheat cropping in rice-wheat system in northwestern India. Nutrient Cycling in Agroecosystems, v.88, p.471-480, 2010. DOI: https://doi.org/10.1007/s10705-010-9370-8.

ZAI, A.K.E.; HORIUCHI, T.; MATSUI, T.; MEHERUNNESA, D. Residual effects of compost and green manure of Pea with other organic wastes on nutrient-use efficiency of successive rice after wheat. Communications in Soil Science and Plant Analysis, v.41, p.2154-2169, 2010. DOI: https://doi.org/10.1080/0 0103624.2010.504797. 